\title{
PERAN KIAI DALAM MENANGANI KESEHATAN MENTAL PASIEN SAKIT JIWA: KASUS DI JAWA TIMUR
}

\author{
Saniri \\ STIT Raden Santri Gresik \\ zaniti45saniri@gmail.com
}

\begin{abstract}
Abstrak
Kiai merupakan agen transformasi sosial budaya masyarakat. Kiai juga merupakan sosok yang kepadanya orang-orang belajar keagamaan, meminta nasihat dan do'a, bahkan juga meminta keputusan tentang perkara yang rumit sampai pada penyembuhan gangguan kejiwaan. Masyarakat pedesaan membutuhkan figur kiai sebagai pendidik dan pembimbing bagi seluruh problematika kesehariannya. Tujuan kajian ini adalah untuk mendeskripsikan peran kiai sebagai pendidik dan pembimbing dalam menangani kesehatan mental pasien sakit jiwa pada sebuah pesantren di Jawa Timur. Kajian ini menggunakan pendekatan kualitatif dengan jenis studi kasus. Teknik pengumpulan data menggunakan: observasi partisipatif, wawancara semiterstruktur, dan dokumen. Keabsahan data yang digunakan dalam penelitian ini adalah triangulasi sumber dan triangulasi tehnik. Penelitian ini menghasilkan peran kiai sebagai pendidik adalah berusaha mendidik pasien sakit jiwa mendayagunakan segala potensinya secara maksimal, baik potensi akal pikirannya, sikapnya, kejiwaannya, dan keimanannya, dengan pendekatan pengetahuan ajaran agama Islam. Peran kiai sebagai pembimbing dilakukan dengan membimbing kejiwaan dan akhlak para santri dengan dimensi spiritual yang berbasis pada tauhid dan prinsip-prinsip ajaran Islam.
\end{abstract}

Kata kunci: kiai, kesehatan mental, pasien sakit jiwa, pesantren

\begin{abstract}
Kiai is an agent of the socio-cultural transformation. Kiai is a person to whom people study religion, consult, and ask for praying and advice how to make decisions on complex matters and how to heal mental disorders. Rural communities need kiai figures as educators and advisers for all their daily problems. The purpose of the study is to describe the role of kiai as an educator and guider in treating mental health of mental patients in East Java. The study involves a qualitative approach with the type of case study. Data collection techniques use participative observations, semi-structured interviews, and documents. The validity of the data used in this study is source and technical trianggulation. The study has produced the role of kiai as a educator is trying to educate mentally ill patients to functionalize their best potential, such as mental potential, attitude, phychic, and faith, with the approach to Islamic knowledge. The role of kiai as a guide is done by guiding the psyche and morals of santri with a spiritual dimension based on tauhid and the principles of Islamic doctrine.
\end{abstract}

Keywords:kiai, mental health, patient of mental disorder, Islamic boarding school 


\section{AL-ADABIYAH: JurnalPendidikan Agama Islam}

\section{Pendahuluan}

Kehidupan modern dewasa ini telah tampil dalam dua wajah yang antogonistik. Disatu pihak, arus modernisasi telah berhasil menunjukkan prestasinya yang spektakuler dalam bidang ilmu pengetahuan dan teknologi. Namun pada saat yang sama, efek negatif dari kemajuan modernisasi telah melahirkan masalah kemanusiaan yang buram berupa kesengsaraan rohaniah. Gejala tersebut muncul sebagai akibat dari modernisasi yang terlalu mengagungkan akal sebagai alat berpikir yang rasionalis (Nashir, 1997: 138).

Ditambah lagi oleh kemajuan yang pesat dalam perkembangan ilmu pengetahun, teknologi, mekanisasi industrialisasi, dan urbanisasi, kehidupan modern menjadi semakin terurai dalam spesialisasi-spesialisasi dan pengotakanpengotakan yang tidak terintergrasi. Semua ini mengakibatkan masyarakat modern semakin terpecah-belah dan sulit diatur. Lantas menampilkan siptom disintergrasi sosial dan disintergrasi individu yang menjadi sebab utama lahirnya mental disorder. Semua itu menegaskan bahwa kebudayaan modern penuh dengan rivalitas, kompetisi, selalu merefleksikan diri dalam bentuk kebudayaan eksplosif atau kebudayaan tegangan tinggi (high tension culture) dengan iklim kompetisi yang sangat melelahkan jasmani-rohani menyebabkan manusia mudah terjangkiti berbagai gejala kekalutan mental serta jauh dari gambaran mental yang sehat (Kartono, 2011: 275).

Di tengah hiruk pikuk kehidupan kota yang serba tergesa-gesa dan selalu pragmatis, seseorang harus selalu berpacu dan bersaing dalam perlombaan hidup. Suasana kompetitif banyak diwarnai spekulatif, manipulatif, obscuur, dan segala tipu muslihat. Hal ini banyak menimbulkan ketakutan dan ketegangan batin pada masyarakat dan menjadi penyebab utama bagi timbulnya macam-macam penyakit mental. Tepatnya, kehidupan modern di kota-kota besar lebih menonjolkan kepentingan diri sendiri dan sikap individualisme sehingga mata dan hati tertutup terhadap penderitaan orang lain, ketenangan hati jadi kering dan hampa, kontak sosial menjadi longgar, manusia satu dengan yang lainnya menjadi semacam atomatom yang terlepas satu sama lain. Dalam kondisi seperti itu, manusia selalu merasa cemas, galau, tidak aman, merasa kesepian dan terasing dalam peradaban besar.

Gambaran di atas diperparah dengan pengaruh lingkungan dan media massayang merangsang gaya hidup materialistis dan hedonis, serta cenderung 


\section{AL-ADABIYAH: JurnalPendidikan Agama Islam}

menuntut standar penghasilan tinggi dan kemewahan materiil. Jika usaha untuk memenuhi semua ini tidak berhasil karena kemampuan untuk mencapainya tidak ada, sedang ambisi dan tuntutan semakin menanjak, maka akan muncul rasa malu, takut, bingung, kecewa, dan rendah diri. Muncul pula agresivitas, ketakutan, dan kecemasan yang kronis atau rasa rendah diri yang dikompensasikan ke dalam bentuk-bentuk dan pola-pola yang gradius (agrandizement/membesarkan diri) dan narsisme, dan semakin suburnya kebudayaan tegangan tinggi yang sangat eksplosif. Akibat bertumpuknya macammacam konflik dan tegangan sosial, tidak sedikit orang lalu menderita gangguan emosional dan kekalutan mental.Banyak terjadi disharmoni dan konflik sosial tanpa konsensus di tengah masyarakat. Maka, berlangsunglah proses disorganisasi pribadi dan disorganisasi sosial yang memunculkan mental disorder (Darajat, 2001: 4).

Pengertian kesehatan mental sendiri secara teoritis adalah terhindarnya orang dari gejala-gejala gangguan jiwa (neurose) dan dari gejala-gejala penyakit jiwa (psychose) (Darajat, 2001: 11). Sementara itu, ciri-ciri dari individu yang memiliki mental yang sehat menurut Killander seperti dikutip oleh Zainal Aqib adalah orangorang yang memperlihatkan kematangan emosional, kemampuan menerima realita, kesenangan hidup bersama orang lain, dan memiliki filsafat/pegangan hidup (Aqib, 2011: 58).

Dalam rangka menangani permasalahan-permasalahan yang menyangkut kejiwaan manusia seperti di atas, dibutuhkan suatu penanganan khusus dengan memakai pendekatan agama. Diantaranya dengan melibatkan pondok pesantren sebagai lembaga agama kemasyaratan melalui peran seorang kiaisebagai seorang pemimpin spritual Islam, pengayom batin, dan dapat dijadikan teladan dalam kehidupan masyarakat muslim sehari-hari. Logika berpikir ini berangkat dari prinsip Islam yang menyebutkan bahwa pada dasarnya manusia terbentuk dari dua dimensi, yaitu dimensi jasmani dan dimensi rohani. Dimana kedua dimensi tersebut harus bisa berjalan secara harmonis sehinggaterbentuk mental yang sehat, baik jasmani maupun rohani.

Dalam menyikapi problem kesehatan mental, ada perbedaan yang mendasar antara masyarakat Barat dan masyarakat muslim, dimana masyarakat Barat modern atau masyarakat yang mengikuti peradaban yang sekuler, solusi yang ditawarkan untuk menangani problem kejiwaan adalah dengan menggunakan pendekatan psikologi yang ilmiah. Sedangkan pada masyarakat Islam, karena 


\section{AL-ADABIYAH: JurnalPendidikan Agama Islam}

mereka (kaum muslimin) pada awal sejarahnya tidak mengalami problem psikologis seperti yang dialami oleh masyarakat Barat, maka solusi yang ditawarkan lebih cenderung bersifat religius spritual (Mubarok, 2003: 185).

Dengan menjadikan al-Quran dan hadist sebagai petunjuk yang sempurna dalam hidup yang akan mengantarkan penganutnya menuju makna hidup dan kebahagiaan yang sebenarnya. Sebagaimana yang disebutkan dalam al-Quran surat al-Isra ayat 82:"Dan kami turunkan dari Al-Quran suatu yang menjadi penawar dan rahmat bagi orang-orang yang beriman dan Al-Quran itu tidaklah menambah kepada orang-orang yang zalim selain kerugian” (Depag, 2005: 234).

Berdasarkan QS. Al-Isra ayat 82 di atas, dapat dipahami bahwa dalam menghadapi kesulitan hidup harus dihadapi dengan rasa optimis dan tidak dengan putus asa, karena firman Allah Swt di atas memberikan petunjuk jalan yang lurus dan juga sebagai pegangan umat manusia dalam menghadapi problem kehidupan sehari-hari.

Menurut hasil wawancara dengan pengasuh pondok pesantren, ditemukan adanya pandangan yang keliru dalam kultur masyarakat. Orang yang mengalami kelainan jiwa pasti disamakan dengan penyakit gila, meskipun pada kenyataannya tidak demikian. Orang yang mengalami tekanan batin, depresi, dan stress masih belum bisa dikatakan gila dan itu masih sangat bisa untuk disembuhkan. Mengingat pondok pesantren merupakan lembaga yang identik dengan sumbersumber ajaran Islam, maka yang digunakan total berasal dari metode bimbingan Islam, yaitu metode spritual melalui metode zikir sebagai bentuk tauhid hambanya terhadap kekuasaan Allah Swt (Wawancara, 5 Februari 2020).

Pada konteks penelitian ini menjadi jelas, jika keberadaan pondok pesantren sebagai lembaga pendidikan kemasyarakatan bisa menunjukkan warna yang multifungsi bagi masyarakatnya. Dengan artian, pondok pesantrennya tidak hanya sebagai sarana pendidikan kurikuler dibidang keagamaan semata, melainkan juga bisa difungsikan sebagai tempat penanganan kesehatan mental bagi para pasien sakit jiwa. Menurut Dhofier (2011: 131), kiai dikenal sebagai guru atau pendidik utama dipesantren. Disebut demikian karena kiai yang bertugas memberikan bimbingan, pengarahan, dan pendidikan kepada para santri.Kiai pulalah yang dijadikan figur ideal santri dalam proses pengembangan diri meskipun pada umumnya kiai juga memilih beberapa orang asisten atau yang lebih dikenal dengan sebutan ustadz atau santri senior. Kiai dalam pengertian umum, adalah pendiri dan pimpinan pesantren. Dia dikenal sebagai seorang muslim terpelajar 


\section{AL-ADABIYAH: JurnalPendidikan Agama Islam}

yang membaktikan hidupnya semata-mata dijalan Allah dengan mendalami dan menyebarluaskan ajaran-ajaran Islam melalui kegiatan pendidikan.

Berdasarkan uraian yang dijelaskan di atas, dapat disimpulkan bahwa kehadiran pondok pesantren dengan melibatkan peran kiaimenduduki posisi yang urgen dalam masyarakat Islam. Keberadaan kiaibeserta perangkatnya telah menjadi sumber tempat dimana orang belajar keagamaan, bisa meminta nasihat, doa, bahkan juga meminta keputusan mengenai soal yang rumit sampai pada penyembuhan ganguan kejiwaan. Hal tersebut dapat dijawab dengan menjadikan kiaisebagai figur pemimpin dan menjadikan pondok pesantren sebagai tempat multifungsi dalam belajar ilmu keagamaan Islam serta sebagai tempat dalam mengadukan berbagai problematika masyarakat.

Berdasarkan penelusuran kajian terdahulu, peneliti banyak menemukan penelitian yang serupa tentang peran kiai dalam menangani kesehatan mental pasien sakit jiwa.Berikut beberapa hasil penelitian yang memiliki kaitan dengan topik pembahasan dalam penelitian ini diantaranya Suteja (2015), Fatimah (2019), dan Heny (2017). Penelitian tersebut sama-sama mengkaji tentang pembinaan kesehatan mental yang diberikan kiai. Kendati sama-sama mengkaji peran kiai, terdapat perbedaan antara kajian terdahulu dengan kajian ini.Fokus penelitian yang dilakukan peneliti pada aspek peran kiai sebagai pendidik dan pembimbing, sedangkan penelitian sebelumnya fokusnya masih bersifat umum. Subyek yang menjadi informan dalam penelitian ini dibatasi pada santri yang diam di pondok, yang tentunya memiliki perbedaan sosial kultural dengan masyarakat luas.

\section{Kajian Teori \\ Peran Kiai}

Dalam studi-studi sosial tentang peranan kiai, ditemukan bahwa peranan kiai memiliki posisi yang strategis dan sentral dalam masyarakat. Posisi tersebut terkait dengan kedudukannya sebagai orang yang terdidik dan disegani dalam kehidupan masyarakat. Sebagai elit terdidik, kiai selalu memberikan pengetahuan tentang wawasan keislaman kepada para penduduk desa dan pesantren sebagai lembaga pendidikan Islam menjadi sarana yang penting dalam melakukan transfer of knowledge.

Terkait dengan peran kiai dalam masyarakat, menurut Lubis (2007: 5), setidaknya kiai memiliki perang yang urgen di tengah-tengah masyarakat yaitu: 1) 


\section{AL-ADABIYAH: JurnalPendidikan Agama Islam}

kiai sebagai pendidik, kiai sebagai pendidik merupakan sumber pengetahuan keagamaan dan sumber nilai-nilai yang dianut bagi santri. Dalam hal ini, kiai mengajarkan ilmu pengetahuan keagamaan sekaligus menanamkan nilai-nilai spiritual dan akhlak mulai kepada santrinya. Selain menjelaskan pentingnya membina sifat-sifat yang mahmudah (baik) dan menghilangkan sifat-sifat yag mazmunah (tercela) pada diri santri. 2) Kiai sebagai pembimbing, posisi sentral dari seorang kiai adalah sebagai pembimbing perilaku/nilai-nilai spiritual. Para santri memandang kiai sebagai figur sentral yang menjadi sumber pengetahuan keagamaan dan sumber nilai-nilai untuk dianut serta tempat utama berkonsultasi bagi setiap masalah kehidupan.

Adapun menurut Dhofier (2011: 131), kiai dikenal sebagai guru atau pendidik utama dipesantren. Disebut demikian karena kiai bertugas memberikan bimbingan, pengarahan, dan pendidikan kepada para santri. Beliau dikenal sebagai seorang muslim terpelajar yang membaktikan hidupnya semata-mata dijalan Allah dengan mendalami dan menyebarluaskan ajaran-ajaran Islam melalui kegiatan pendidikan.

Dari beberapa peran kiai yang telah disebutkan di atas, semua mengartikan bahwa kedudukan kiai memiliki peran yang vital bagi santri dan masyarakat. Bisa diartikan peran kiai dalam semua sektor kehidupan sangatlah penting, karena kiai dalam konteks sosial dipandang sebagai seseorang yang dipercaya dan disegani oleh masyarakat luas. Kiai merupakan sektor kepemimpinan Islam yang dianggap paling dominan baik pada aspek perkembangan sosial (social), kebudayaan (culture), keagamaan (religion), dan pendidikan (education).

\section{Kesehatan Mental}

Sehat dan sakit adalah keadaan biopsikososial yang menyatu dengan kehidupan manusia. Pengenalan manusia terhadap kedua konsep ini kemungkinan bersamaan dengan pengenalannya terhadap kondisi dirinya sendiri. Dengan artian, konsep "sehat" dan "sakit" merupakan bahasa sehari-hari dan dikenal dalam setiap kebudayaan. Meskipun demikian, untuk menentukan pengertian sehat dan sakit secara pasti tidaklah mudah. Kesamaan perspektif atau kesepakatan dalam merumuskan pengertian kedua konsep tersebut secara universal merupakan hal yang tidak mudah. Namun, ada beberapa acuan yang 


\section{AL-ADABIYAH: JurnalPendidikan Agama Islam}

dapat dijadikan standart dalam mengartikan konsep tersebut yang akan dibahas pada bab ini.

Secara etimologi, istilah kesehatan mental diambil dari konsep mental hygiene. Kata mental diambil dari kata Yunani, pengertinya sama dengan psyche dalam bahasa Latin yang artinya psikis, jiwa atau kejiwaan. Jadi, istilah mental hygiene dimaknakan sebagai kesehatan mental atau kesehatan jiwa (Notosoedirjo, 201: 63). Adapun pengertian kesehatan mental secara etimologi adalah terhindarnya orang dari gejala-gejala gangguan jiwa (neurose) dan dari gejala-gejala penyakit jiwa (Daradjat, 1984: 11). Pada teori yang lain, dijelaskan bahwa cirri-ciri individu yang memiliki mental yang sehat yaitu orang-orang yang memperlihatkan kematangan emosional, kemampuan menerima realita, kesenangan hidup bersama orang lain, dan memiliki filsafat/pegangan hidup, serta mampu menyesuaikan diri dengan diri sendiri, dengan orang lain, masyarakat serta lingkungan dimana ia hidup (Aqib, 2015: 42).

Dari beberapa pengertian di atas, dapat dipahami bahwa yang dimaksud dengan kesehatan mental adalah kemampuan untuk menyesuaikan diri dengan diri sendiri, orang lain, dan masyarakat dimana ia berada sehingga terbentuk keserasian yang harmonis antara akal dan hatinya serta terhindar dari gejala gangguan jiwa dan gejala penyakit jiwa atau pertentangan batin (konflik). Seseorang yang sehat mentalnya akan mampu menyesuaikan diri yang akan membawa kepada kenikmatan hidup dan terhindar dari kecemasan, kegelisahan, dan ketidakpuasan. Disamping itu, seseorang yang sehat mentalnya dapat menguasai segala problem dalam kehidupannya, sehingga dapat menghindari dari tekanan-tekanan perasaan atau hal-hal yang membawa kepada frustasi.

\section{Metode}

Kajian ini menggunakan pendekatan kualitatif dalam rangka memahami fenomena tentang peran kiai dalam menangani kesehatan mental pasien sakit jiwa. Subyek kajian dipilih secara purposif dengan pertimbangan bahwa mereka adalah narasumber yang dapat memberikan informasi dan data sesuai fokus kajian (Sugiyono, 2014: 52), yang terdiri atas: kiai selaku pengasuh pondok, istri pengasuh pondok, asisten kiai, keluarga pasien, dan beberapa masyarakat sekitar pondok pesantren. 


\section{AL-ADABIYAH: JurnalPendidikan Agama Islam}

Data-data dalam kajian ini dikumpulkan menggunakan teknik observasi partisipan, wawancara semiterstruktur dan dokumen.Observasi partisipan dilakukan dengan cara peneliti melibatkan diri dalam kegiatan bimbingan kiai dengan santri sehingga peneliti dapat menangkap dan merasakan apa yang terjadi selama kegiatan bimbingan berlangsung.

Wawancara semiterstruktur dipilih untuk memastikan bahwa peneliti mampu menggali informasi selengkap-lengkapnya sesuai fokus kajian yang disusun dalam sebuah pedoman wawancara. Pedoman itu dijadikan panduan untuk mewawancarai subyek penelitian yang dipilih secara purposif tadi. Agar datanya terekam dengan baik, maka peneliti memakai alat perekam yang ada di smart phone.Hasil rekaman itu kemudian ditranskrip secara seksama menjadi transkrip wawancara.

Teknik dokumen digunakan untuk mendukung data-data yang diperoleh melalui observasi dan wawancara. Selain dokumen yang sesuai fokus kajian, peneliti juga mengumpulkan dokumen yang berkaitan dengan kegiatan penanganan pasien sakit jiwa pada aspek fisik dan kegiatan penanganan pasien sakit jiwa pada aspek mental.

Data-data yang dipandang kredibel itu kemudian dianalisis menggunakan model interaktif Miles dan Huberman (1994) yang meliputi: reduksi data, penyajian data, dan simpulan.Keabsahan data yang digunakan dalam penelitian ini adalah triangulasi.Triangulasi adalah teknik pengumpulan data yang bersifat menggabungkan dari berbagai teknik pengumpulan data dan sumber data yang telah ada (Sugiyono, 2014: 241), sedangkan untuk menguji keabsahan data yang diperoleh, peneliti menggunakan trianggulasi sumber dan triangulasi teknik.

\section{Hasil dan Pembahasan}

Dalam realitas sosial, pondok pesantren merupakan sebuah lembaga pendidikan yang terus bergerak bersama ruang dan waktu dalam merespon dan melayani kebutuhan masyarakat yang semakin kompleks dengan berbagai macam persoalan sosial kemasyarakatan yang ada.Salah satunya terkait fenomena sosial yang telah dijelaskan di atas, yaitu menyangkut tentang kesehatan mental yang akhir-akhir ini menurun dengan drastis akibat sisi negatif dari globalisasi. 


\section{Peran Kiaisebagai Pendidik dalam Menangani Kesehatan Mental Pasien Sakit Jiwa}

Berdasarkan hasil observasi peneliti, diketahui bahwa pesantren ini merupakan suatu yayasan yang aktif dalam melakukan berbagai aktivitas.Dari tahun ke tahun, pesantren mengalami peningkatan dari segi kuantitas jumlah pasien dan penderita gangguan jiwa. Hal ini terbukti pada tahun 2018, jumlah total keseluruhan pasien dan penderita gangguan jiwa hanya sebanyak 69 orang. Namun pada tahun 2019, total keseluruhan pasien dan penderita gangguan jiwa berjumlah sekitar 95 orang. Gambaran tersebut menunjukkan bahwa kepercayaan masyarakat luas terhadap pesantren ini semakin besar. Gambaran tersebut diperkuat dengan adanya aktivitas keagamaan dan aktivitas penunjang kesehatan mental, dimana tempat kediaman kiai menjadi tempat konsultasi bagi pasien sakit jiwa dan masyarakat yang ingin mencurahkan segala permasalahannya.Dimana kiai dengan senang hati mempergunakan waktu senggangnya untuk dijadikan waktu konsultasi. Kiai akan memberikan layanan konsultasi pada saat siapa saja yang membutuhkannya, meskipun waktu yang diperlukan untuk melakukan kegiatan konsultasi mungkin harus dengan beberapa menit.

Dalam melakukan langkah-langkah metode terapi curahan hati, kiai selalu memberi kebebasan penuh bagi anak-anak dalam mengeluarkan unek-uneknya dengan caranya sendiri. Dengan cara mendengarkan dengan seksama dan membiarkan yang bersangkutan menceritakan segala permasalahannya, maka kiai dapat mengetahui titik permasalahan dalam rangka agar kiai dapat mengklasifikasikan permalasahan pasien termasuk pada jenis apa problemnya. Apabila terkait dengan gangguan psikis murni, pasien diberi arahan dan dibimbing sesuai petunjuk yang tertuang dalam al-Quran agar jiwa dan pikirannya menjadi tenang, tetapi kalau problemnya mengenai kerasukan roh halus baru diambil tindakan lain (Wawancara, 5 Februari 2020).

Setiap permasalahan selalu menuntut adanya penyelesaian. Di saat seseorang tidak mampu memecahkan dan menyelesaikan permasalahannya secara mandiri, bahkan merasa tidak berdaya untuk memahami permasalahannya dan dirinya sendiri, maka pada saat itu dia membutuhkan seseorang yang memiliki peran profesionalitas dalam bidangnya. Dalam hal ini, kiai dengan segala kemampuannya berusaha mendidik bagaimana seharusnya yang bersangkutan dapat mengembangkan potensi akal pikirannya, kejiwaannya, dan keimanannya, 


\section{AL-ADABIYAH: JurnalPendidikan Agama Islam}

serta dapat menanggulangi semua problematikanya secara baik dan mandiri dengan tetap mengacu pada ajaran agama Islam.

Keterangan data wawancara di atas diperkuat oleh hasil keterangan dari asisten kiai bahwa sebagai orang awam yang tidak mengetahui apa-apa tentang pengetahuan agama, beliau tidak segan-segan untuk datang kepada kiai untuk bertanya dan menceritakan semua permasalahannya. Dengan menceritakan semua problemnya, yang bersangkutan berharap kiai dapat memberi solusi sesuai petunjuk ayat-ayat yang ada dalam al-Qur'an dan menghubungkannya dengan cerita suka dukanya Rasulullah (Wawancara, 22 Februari 2020).

Pada konteks yang sama, seorang warga setempat menyampaikan kepada peneliti bahwasanya kiai menjadi rujukan masyarakat dalam meminta petunjuk. Ibaratnya kiai sudah menjadi guru spritual di kabupaten yang terkenal dengan tapenya ini.

Berbagai pernyataan di atas menegaskan bahwa masyarakat membutuhkan pendidik dalam segi rohaniah, dan menjadikan peran kiai sebagai sumber dalam meminta petunjuk dan bimbingan dalam upaya meningkatkan kualitas iman dan ketakwaan mereka. Bertolak dari hal tersebut, segala petunjuk yang terdapat dalam al-Quran dan hadist dapat dijadikan pedoman untuk membantu manusia dalam mendidik dan mengendalikan keinginan dalam setiap tindakannya.Hal ini menjadi penting, karena pengetahuan agama Islam menekankan keseimbangan antara pikiran dan jiwa manusia. Dari sini, maka peran kiai sebagai pendidik dibutuhkan sebagai seseorang yang berperan merekonstruksi dan berusaha mengaktualisasikan kembali konsep diri manusia dengan pendekatan pengetahuan ajaran agama Islam.

Temuan tersebut sesuai pandangan Lubis (2007: 328), kiai sebagai pendidik merupakan sumber pengetahuan keagamaan dan sumber nilai-nilai yag dianut bagi santri. Dalam hal ini, kiai mengajarkan ilmu pengetahuan keagamaan sekaligus menanamkan nilai-nilai spiritual dan akhlak mulia kepada santrinya. Selain itu, kiai berkewajiban mendidik sifat-sifat yang fadilah (utama) dan menghilangkan sifat-sifat yagmazmunah (tercela) pada diri santri, dengan menjadikan dirinya sebagai teladan yang nyata dalam kehidupan sehari-hari. Hal ini merupakan upaya pembinaan kesehatan mental para santri dan dapat pula dimaknai sebagai upaya yang bertujuan untuk menjaga ketenangan hati dan ketentraman jiwa para santri. 


\section{AL-ADABIYAH: JurnalPendidikan Agama Islam}

Keutamaan dalam mendidik keselarasan antara fisik dan mental juga didukung oleh teori cutting yang dikutip oleh Notosoedirjo (2016: 9), bahwa kesehatan fisik dan mental itu saling berhubungan, artinya jika yang satu terganggu akan membawa pengaruh kepada bagian yang lainnya. Hubungan antara keduanya sangat kompleks meskipun tidak dapat dinyatakan bahwa satu aspek menentukan yang lainnya.

\section{Peran Kiai sebagai Pembimbing dalam Menangani Kesehatan Mental Pasien Sakit Jiwa}

Dalam realitas sosial, pondok pesantren merupakan sebuah lembaga pendidikan yang terus bergerak bersama ruang dan waktu dalam merespon dan melayani kebutuhan masyarakat yang semakin kompleks dengan berbagai macam persoalan sosial kemasyarakatan yang ada. Salah satunya terkait fenomena sosial yang telah dijelaskan di atas, yaitu menyangkut tentang kesehatan mental yang akhir-akhir ini menurun dengan drastis akibat sisi negatif dari globalisasi.

Fenomena-fenomena tersebut secara nyata dapat menggiring seseorang kepada persoalan-persoalan kejiwaan, berupa pertentangan batin yang berkecamuk dalam dirinya. Pertentangan batin akan terungkap dan mengambil bentuk dalam berbagai rupa, seperti halnya perasaan cemas yang tidak menentu, menjauhkan diri dari masyarakat, menjauhkan diri dengan Allah Swt, tenggelam dalam khayalan untuk memenuhi apa yang tidak mungkin dicapai dalam kenyataan. Dimana semua pertentangan batin tersebut dapat menyebabkan kesehatan mentalnya terganggu sehingga muncullah apa yang dinamakan disorder mental atau gangguan jiwa.

Dikarenakan manusia tidak dapat membebaskan dirinya dari problem kehidupan yang melingkari perjalanan hidupnya, maka seluruh problem itu menuntut adanya penanganan dengan tepat dan sesuai. Salah satu bentuk penanganan tersebut dapat dilakukan melalui pengobatan yang disediakan pondok pesantren melalui peran kiai sebagai pemegang kendali utama pondok serta seseorang yang dianggap sangat akrab dalam membimbing dan menyelesaikan permasalahan kehidupan dalam masyarakat kultur Jawa dan Madura. Dalam hal ini, peran kiai dianggap mampu membantu masyarakatnya menganalisis problem materialnya (empirik), agar secara mental ia dapat menerima persoalan yang dimaksud, serta sekaligus dapat memahami dan mengetahui cara pemecahan atau penyelesaiannya. Dengan demikian, peran kiai diharapkan dapat menangani 


\section{AL-ADABIYAH: JurnalPendidikan Agama Islam}

penyakit mental yang dideritanya agar yang bersangkutan dapat kembali berinteraksi sosial secara normal dengan mental yang sehat.

Menurut keterangan istri kiai (Wawancara, 5 Februari 2020) yang disampaikan kepada peneliti ditemukan bahwasanya menangani orang yang sedang sakit mentaldibutuhkan kesabaran yang ekstra tinggi karena semakin anak-anak dikasari, maka semakin sulit mentalnya untuk stabil. Dalam proses bimbingan tersebut, yang terpenting adalah bagaimana kiai dapat membimbing kejiwaan yang bersangkutan dekat dengan Allah Swt sebagai sumber dari segalanya dan yang terpenting lagi yaitu membimbing sikap anak-anak agar dapat membedakan mana yang sopan dan tidak. Bimbingan dan arahan tersebut diwujudkan Kiai dengan sering membiasakan anak-anak berpakaian yang rapi dan sopan, mengajari perkataan yang baik, makan dengan tangan kanan, dan lain sebagainya.

Keterangan yang sama juga disampaikan kiai kepada peneliti bahwasanya menangani orang yang sedang mengalami goncangan batin harus dengan kepedulian dan kasih sayang yang tinggi. Dalam proses bimbingan ini, yang terpenting adalah bagaimana menumbuhkan kepercayaan diri pasien untuk secara mandiri bisa mengatasi permasalahannya sendiri dan menjadikan al-Qur'an sebagai obat penawar dalam setiap kesulitan. Dengan demikian, kiai tidak hanya mengarahkan ketenangan berpikir namun juga memberi tuntunan bagaimana mereka mendapat ketenangan batin(Wawancara, 5 Februari 2020).

Pernyataan di atas mengartikan jika kesehatan mental manusia dapat terganggu salah satunya berawal dari ketidakmampuan potensi dirinya dalam menahan hawa nafsunya. Bertolak dari hal tersebut, segala petunjuk yang terdapat dalam al-Qur'an dan hadist dapat dijadikan pedoman untuk membantu manusia dalam mendidik dan mengendalikan keinginan dalam setiap tindakannya. Hal ini menjadi penting, karena pengetahuan agama Islam menekankan keseimbangan antara pikiran dan jiwa manusia. Dari sini, maka peran kiai sebagai pendidik dibutuhkan sebagai seseorang yang berperan merekonstruksi dan berusaha mengaktualisasikan kembali konsep diri manusia dengan pendekatan pengetahuan ajaran agama Islam.

Keterangan data wawacara di atas diperkuat oleh hasil observasi peneliti, yang menemukan bahwa pesantren ini memang menjadi tempat rujukan bagi masyarakat sekitar pesantren yang mempunyai permasalahan pribadi hingga permasalahan agama.Dalam kegiatan bimbingan rohani tersebut, kiai 


\section{AL-ADABIYAH: JurnalPendidikan Agama Islam}

melakukannya secara individual dan kelompok, tatap muka langsung antara kiai dan masyarakat. Kiai juga merangkap sebagai ustadz, sekaligus konselor yang tidak hanya memberikan bimbingan dalam menuntun akal/pikiran pasien, tetapi juga menuntun nurani/qalb mereka dengan meningkatkan kualitas iman dan ketakwaan kepada Allah. Adapun metode terapi yang digunakan kiai tergantung persoalan yang dialami oleh pasien. Persoalan sederhana umumunya diselesaikan dengan metode curahan hati dan terapi dzikir, apabila yang bersangkutan mengalami depresi bahkan sampai mengalami kegoncangan yang akut, maka kiai menggunakan metode mandi malam.

Terkait terapi bimbingan di atas, keterangan yang sama disampaikan oleh asisten kiailainnya (Wawancara, 2 Maret 2020) bahwa dalam melakukan kegiatan bimbingan rohani individual, ada cara dan tahapannya sendiri-sendiri. Untuk pasien yang baru berasal dari jalanan yang masih kotor, mempunyai kebiasaan telanjang, buang kotoron di tempat, makan dari tempat sampah, biasanya dibersihkan dahulu, baru pada waktu malamnya kiai menggunakan terapi mandi malam. Tujuan dari terapi mandi malam yaitu untuk mengembalikan kebiasaankebiasaan pasien seperti manusia pada umumnya yang sehat secara jasmani dan rohani. Proses terapi tersebut biasanya dilakukan pada pukul 22.00 WIB, dan dilakukan selama kurang lebih satu jam. Awalnya terapi mandi malam dilakukan di dalam kamar mandi yang agak luas dengan cara menyemprotkan air kembang dengan selang yang bertegangan tinggi dari kepala hingga kaki secara berulangulang sampai pasien menunjukan perubahan yang lebih tenang dan sesekali dilakukan pemijatan pada kepala, yang bertujuan untuk mengendorkan syarafsyaraf yang tegang, kemudian pasien di masukan ke dalam kolam untuk berendam.

Keterangan yang sama juga disampaikan asisten ketiga kiai peneliti (Wawancara, 2Maret 2020) bahwa kebanyakan kasus sakit jiwa diawali dari hal-hal yang sepele, misalnya keinginan memiliki kendaraan bermotor namun tidak kesampaian akhirnya menyendiri sampai-sampai tidur dikandang ayam, ada yang kecanduan narkoba karena faktor pergaulan. Bahkan menurut pengakuan beliau, ada pasien baru datang dari Lamongan yang depresi karena mendalami ilmu pesugihan. Dari semua kasus tersebut, jelas kalau problematika kejiwaan berasal dari faktor Sumber Daya Manusia (SDM) yang minim. Bertolak dari kasus-kasus tersebut, Kiai selaku pembimbing secara perlahan membimbing anak-anak dengan pengetahuan agama berdasarkan al-Qur'an dan hadist. 


\section{AL-ADABIYAH: JurnalPendidikan Agama Islam}

Pondok pesantren ini dibangun di atas dimensi spritual yang berorientasi pada prinsip-prinsip ajaran Islam. Dalam konteks tersebut, maka peran kiai yang utama adalah membimbing psikologis pasien sakit jiwa dengan dimensi spiritual berbasis penegakan tauhid. Dalam artian, kiai berusaha membimbing kejiwaan pasien sakit jiwa pada kesehatan rohaniah agar beriman dan bertaqwa kepada Allah Swt. Membimbing dimensi rohaniah yang berprinsip pada al-Qur'an dan hadist juga selaras dengan tujuan pendidikan Islam dalam rangka membangun kehidupan sakinah, sebab kehidupan tidak hanya sebatas pada kesehatan fisik melainkan juga ketenteraman spritual yang akan menghasilkan kesehatan mental.

Dalam bentuk yang lain, guna semakin memaksimalkan proses penyembuhan mental para pasien, selain membimbing pasien dalam tataran teoritis yang bersifat lisan, kiai juga mempunyai metode terapi yang digunakan sebagai alat dan merupakan suatu alternatif dalam mempercepat proses penyembuhan. Dengan artian, metode terapi tersebut digunakan sebagai amplikasi yang nyata dalam membimbing individu agar dapat mencapai kesehatan mental. Pendayagunaan metode terapi tersebut tentu saja secara tegas mengacu pada asasasas ajaran Islam yang bertujuan membentuk jalinan hubungan antara hamba dengan pencipta-Nya sehingga terjadi sinkronisasi antara keinginan manusia dengan kehendak Allah yang pada gilirannya akan menghasilkan hamba-hamba yang selalu dekat dengan Allah Swt.

Temuan tersebut selaras dengan penjelasan Lubis (2007: 137), bahwa kegiatan bimbingan individual yang mengarahkan pasien pada potensi tauhid dalam bimbingan konseling Islam disebut sebagai Spiritualism Method, yaitu suatu metode terapi penyembuhan yang mengarahkan pasien mencari ketenangan hati dengan cara mendekatkan diri dan meyakini kepada Allah Swt sebagai sumber ketenangan batin, sumber kekuatan dan penyelesaian masalah, dan sumber penyembuhan penyakit mental.

Adapun menurut Rohmah (2013: 272-3), bahwa ada beberapa cara dalam metode Islam yang digunakan untuk mencegah timbulnya penyakit kejiwaan dan sekaligus menjaga kondisi kesehatan mental seseorang, salah satunya yaitu melatih dan membiasakan diri untuk sering melakukan kegiatan spiritual-religius yaitu mengintensifkan dan meningkatkan kualitas ibadah, seperti berdzikir kepada Allah Swt dalam keadaan suka dan duka.

Temuan data tersebut, juga sesuai dengan teori tentang peran kiai sebagai pembimbing dalam masyarakat yang dinyatakan Moesa (2004: 211) yang 


\section{AL-ADABIYAH: JurnalPendidikan Agama Islam}

menyebutkan bahwa peran kiai adalah sebagai tokoh agama menjadi figur penting dalam struktur masyarakat Islam. Posisi penting kiai dalam masyarakat tidak terlepas dari karakteristik pribadinya yang sarat dengan berbagai nilai lebih. Pada kepribadian kiai melekat kuat otoritas karismatik karena ketinggian ilmu agamanya, kesalehannya, dan kepemimpinannya. Kondisi inilah yang menjadikan Kiai diposisikan oleh masyarakat sebagai uswatun hasanah, yaitu contoh atau panutan yang baik dalam lingkungan masyarakat.

\section{Kesimpulan}

Peran kiai sebagai pendidik dalam menangani kesehatan mental pasien sakit jiwa adalah berusaha mendidik pasien sakit jiwa mendayagunakan segala potensinya secara maksimal, baik potensi akal pikirannya, sikapnya, kejiwaannya, dan keimanannya, dengan pendekatan pengetahuan ajaran agama Islam. Apabila segala potensi tersebut bisa berjalan dengan baik maka diharapkan kepercayaan diri pasien sakit jiwa akan kembali tumbuh dan akhirnya akan semakin berpengaruh positif terhadap kesehatan mentalnya. Peran kiai sebagai pembimbing dalam menangani kesehatan mental pasien sakit jiwa dilakukan dengan membimbing kejiwaan dan akhlak para santri pasien dengan dimensi spiritual yang berbasis pada penegakan tauhid, yaitu berusaha membimbing dengan tetap mengacu pada prinsip-prinsip ajaran Islam guna menjadikan kesehatan mental yang selalu beriman dan bertaqwa kepada Allah Swt.

\section{Referensi}

Aqib, Zainal. (2015).Konseling Kesehatan Mental. Bandung: CV Yrama Widya.

Daradjat, Zakiyah. (1984).Kesehatan Mental. Jakarta: Haji Masagung.

Dhofier, Zamakhsyari. (2011).Tradisi Pesantren "Studi Pandangan Hidup Kiai dan Visinya Mengenai Masa Depan Indonesia". Yogyakarta: LP3ES.

Fatimah, Santi Siti. (2019). "Metode Ruqyah Terhadap Kesehatan Mental Santri Pondok Pesantren Jolo Sutro Adijaya Terbanggi Besar Lampung Tengah", Skripsi, Institut Agama Islam Negeri Metro Lampung, 2019.

Heny, Nur. (2017). "Kesehatan Mental Perspektif Zakiah Daradjat", Skripsi, Institut Agama Islam Negeri Salatiga.

Kartono, Kartini. (2011).Patologi Sosial.Jakarta: Rajawali Press.

Lubis, Saiful Akhyar. (2007).Konseling Islami "Kiai dan Pesantren". Yogyakarta: Elsaq Press. 
Miles, Matthew B. and A. Michael Huberman. (1994).Qualitative Data Analysis: An Expanded Sourcebook. California: Sage.

Moesa, Ali Maschan. (2004).Agama dan Demokrasi "Komitmen Moeslim Tradisional Terhadap Nilai-Nilai Kebangsaan". Surabaya: Pustaka Dai Muda.

Mubarok, Achmad. (2003). Meraih Kebahagiaan Dengan Bertasawuf "Pendakian Menuju Allah".Jakarta: Paramadina.

Nashir, Haedar. (1997). Agama dan Krisis Kemanusiaan Modern. Yogyakarta: Pustaka Pelajar.

Notosoedirdjo, Moeljono. (2016).Kesehatan Mental "Konsep dan Penerapannya". Malang: Universitas Muhammadiyah Malang Press.

Rohmah, Noer. (2013).Pengantar Psikologi Agama.Yogyakarta: Teras.

Sugiyono. (2014) Memahami Penelitian Kualitatif. Bandung: Alfabeta.

Suteja, Jaja. (2015). "Peran Kiai dalam Pembinaan Mental Spiritual Santri Remaja di Pondok Pesantren Kota Cirebon: Studi Multisitus di Pondok Pesantren Jagasatru,, Al-Istiqomah, Ulumuddin, dan Madinatunnajah Kota Cirebon" Orasi, Vol. VI No. 1. 